\title{
Challenges faced by the Hotel Industry: a review of Indian Scenario
}

\author{
Gaurav Kashyap \\ Assistant Professor University Institute of Hotel Management \& Tourism Panjab University, Chandigarh
}

\begin{abstract}
This study examines the difficulties faced by the Indian hotel industry as a whole including the challenges faced by the owners as well as the Management and operational staff working in it in recent times. It is a well known fact that competition for the survival in the industry has been getting tougher with every passing year and the fact of the matter is that industry is still gradually growing at a constant rate of about $5-7 \%$ per annum since few years. Occupancy level in hotels all over India has been reported as getting lower and discounts percentages getting higher affecting Rev-par, which has almost halved in these six-seven years. Though, Industry is very hopeful for future growth and expecting sunny days as the room inventories are increasing on daily basis, thus creating more opportunities for the service staff. This study follows the flaws in some of the government policies directly related to Hotel Industry which are effecting hotels and also discusses other issues related to hotel Industry as well such as Taxation Policies of Indian Government, Debt- funding by Indian Banks, Licensing Issues, Visa Issues, Descending Indian economy, Online Travel Agents, Guest Profiling, Human Resource Management, Quality of Guest Services in the era of Social Media, Safety and Security etc. These are few of the most important concerns which have a long lasting effect upon the business of the hospitality.
\end{abstract}

Key Words: Hotel Industry, Challenges, Rev-par, Occupancy, Government policies, Indian Economy

I. Challenges faced by the Hotel Industry: a review of Indian Scenario

Historically, building a good hotel has always been a huge task, but in these times of $21^{\text {st }}$ century it is gigantic due to manifolds increase in the prices of nearly each and everything that is required to make a hotel of the best standards. Hotels usually are a spectacular display of architecture combined with luxury at its best and conventionally are built in accord with the contemporary and futuristic designs with distinction for not only the exterior outlook but at the same time interiors are also given a chic and edgy styles with an intricate eye for details on every aspect.

Hotel Industry is ever evolving, ever changing not by its nature but due to the need of an hour. New and progressive concepts like Boutique Hotels, Green Hotels, and Healthy Hotels have emerged in the market with time, leading to the evolution and growth of new trends in the hotel industry. Industry has always operated in a same manner (i.e. "it acts for adopting the changes brought by the new introduced trends and technology"), ever since the time of the first hotel of the globe i.e. "The Tremont". Industry caters to the people who are away from their home places and are ready to pay for the price of the services provided by the hotel. Generally these customers are treated like guests and i.e. why hotels are known to be home away from a home.

No matter how magnificently any hotel is built, its revenue flows from the number of guests staying in the hotel's room or utilizing any other services of hotel like its restaurants, bar, banquets, conference halls, spa, gym, beauty salon, swimming pools etc. It is a direct customer based industry whose main focus is towards the customer's satisfaction and customer retention so as to earn their long term loyalty towards their brand. It is a big challenge for all the hotels to retain their customers, no... "Guests", as with the advent of new trends in architecture, designs and technology and environment friendly and healthy hotels concepts, companies have been coming up with hotels which are being built incorporating all or some of these components in a building which is made while keeping in mind the fact that it is an investment for the future. With each passing day competition among the hotels for their own survival is becoming fierce and they are facing some modern day challenges in their daily operations those are directly or indirectly related to the revenue generation through customer satisfaction, retention and loyalty. We will discuss challenges which may be owner based or customer based in details -

\section{Indian Government's Taxation Policies}

India is facing a slump in the Hotel Industries for approximately five years now. It is facing low occupancy and declining Rev-par over these years. "The general slowdown in the economy has hit the hotel industry. Over the last two years, average room rates have definitely reduced and occupancy has been stagnant," said SM Shervani, president of the Federation of Hotels and Restaurant Associations of India (FHRAI) as reported by Khosla \& Sathyanarayanan in 2014. In India, hotels are taxed anywhere between $20 \%$ and $25 \%$ 
depending on the state that they are operating in, when other Asian countries are levying 8-10\%. In addition to this, different tax structures in different states are difficult for tourists to comprehend. The ongoing economic slowdown has further hurt the sector as it affected both business and leisure travel. In fiscal 2012-13, occupancy rates in the sector dropped to a decade low of $58.3 \%$ and the average room rates fell to the lowest in six years at Rs 6,214, according to HVS in 2013. After the government unveiled its budget for fiscal 2013-14, the FHRAI had said that industries such as hospitality, which are particularly sensitive to volatility in economic cycles, should have been offered support in the form of tax relief and other fiscal incentives (Khosla \& Sathyanarayan, 2014). Not to mention that taxes ultimately are levied through the customer's pocket, whereas, if some tax relaxations are given to the hospitality industry it will provide a boost to the hotels in terms that they will have more operational cost to run their business and financial support to reduce the risk of failures and give endurance to sustain through the slack times. The saved money could find a place in annual budget of the hotel's operations to increase the ADR and Rev-par through the customer retention strategies opted by the hotels.

\section{Debt-funding by the Indian Banks}

HVS India in September 2013 researched the lending parameters prevalent in select other countries of the world for hotel debt-funding and compared them to the prevailing conditions here. Expectedly, it was found that in cities such as New York, London, Dubai and Moscow, the term period of the loan ranges from 20-30 years, with interest rates of $5-7 \%$. In other cities such as Beijing and Buenos Aires, while the length of the loan term is around 10 years, the interest rate is in the range of $9-10 \%$. In clear contrast, debt-funding for hotel projects in India is characterised by a relatively short loan term, typically of 10-12 years, but with high interest rates of 12-14\%. Hotel owners want the next government to reduce interest rates on loans for the industry. "In the last decade, interest rate for new projects has been hiked from $8.00-8.25 \%$ to $12.50 \%$," said Ashish Jakhanwala (in 2014), managing director of SAMHI Hotel Investment. Discussions with mortgage brokers and subject matter experts reveal that the lending parameters for hotels projects in India border on being unfriendly towards the borrowers. It is common knowledge that hotels in India typically have a construction period of 3-3.5 years. With a loan term of 10 years, the door-to-door tenure can be broken down as 3-3.5 years (construction period) +1 year (moratorium on interest payment) $+5.5-6$ years (operations period). Therefore, the project only has 5.5-6 years to pay for the debt service, which is unrealistic. As a result, the insufficient payback period leads to either the borrower putting in more equity to pay-off the debt, which ideally should be coming from the cash flows of the hotel itself or the project undergoing refinancing/re-structuring, which is a very common occurrence these days. "A new hotel project typically takes anywhere between three and five years if you include regulatory delays. Debt repayment begins as soon as a project hits the ground and hotel owners are unable to access public capital, making repayment cycles longer than before," Jakhanwala said.

\section{Licensing Issues}

It is a well known fact among the local and international investors that India is a difficult country to start a business. It ranks 132 among the 185 countries in terms of ease of doing business due to issues related to licensing. The current regulatory environment in the country makes hotel development a difficult terrain for owners. Beginning with the land acquisition stage, for which the archaic laws differ from state-to-state, to securing approvals and licenses, an owner faces bureaucratic bottlenecks irrespective of whether he uses a topdown or a bottom-up approach to cut through the red tape, though the former is likely to yield quicker results. There are numerous licenses and approvals (can add up to more than a 100 in some states) that one needs to get in present times to open a hotel in India leading to loss of time, effort and money. Furthermore, the various bodies giving approvals/issuing licenses tend to work in independent silos, leaving the coordination up to the applicant.

D. S. Advani, President HRAWI (Hotel and Restaurant Association of Western India) and Vice president FHRAI say that licensing is a daunting issue in India. "All states in India have their own set of licensing challenges; Maharashtra in particular needs in excess of 100 licensing permissions to just get a hotel started. After this innumerable and unnecessary authorizations needed for day to day operations. While Gujrat is a dry state and is hence exempted from the headache of liquor licenses, hotels in Maharashtra have to take a daily liquor license for every event they do, making it practically impossible to throw parties at the last minute. Kamlesh Barot Director -VIE Hospitality, Immediate Past President FHRAI and HRAWI says, Police licenses/registration certificates have to be renewed annually, the Christmas and New Year functions are an annual affair, yet there is no blanket sanction till the eve of the event day, and the permission is given at the last minute. Also, multiple clearances are required to be obtained from various authorities, despite being licensed premises for banquets, wedding and events. At present a hotel has to take more than one license under the state excise for various locations within the same premises. 


\section{Descending Indian Economy puts branded Hotels on Sale}

Shah in 2014 said that around six years ago, a night at a luxury hotel in the Delhi region cost on average Rs.10,429-about $\$ 259$ at the time and on par with several five-star hotels in Singapore. Occupancy rates were an enviable $74 \%$, according to hospitality consultants HVS, as business travellers flocked to India, an economy that was then growing at nearly $10 \%$. Since then, economic growth has halved, reducing the flow of corporate guests who make up about $70 \%$ of the business for five-star hotels in cities like Delhi and Mumbai. Average room rates in the capital region have also almost halved to around Rs. 6,850, while occupancy rates were found $55 \%$ only.

The declining economies, and revenues, have sparked a blame-game between hotel owners and operators, prompting the "reflagging" of several properties. Operators say the owners are demanding unrealistic returns after over-leveraging themselves, while owners say operators over-promised on performance. "The relationship is breaking because somebody made a promise and the reality is far from the promise - both due to economic reasons and sometimes due to performance lapses," said Ashish Jakhanwala , Chief Executive of Samhi, an Indian firm that owns hotels, in an interview with Aditi Shaw in 2014. Rajeev Kaul, President, Leela Hotels, states "This is India's first cycle of sales across the country. When supply increases, and demand has not caught up, some churning takes place. The demand is not there and it is not keeping with the supply." $\mathrm{He}$ reiterates, that "many of the new owners are developers of the real estate. The rate of return on investment is not always what they thought what it would be. There is no or very little emotional quotient with hospitality business, per se. The highs and lows in the business will always be there, as in any other business. Hotels as an asset class has always under performed as against the real estate classes, purely in terms of ROI. Ten years ago, our performance was amongst the best, and many got lured blindly into the business, while many new players joined the business."

Some 60 branded hotels are up for sale in India says K. B. Khachru, Chairman, Carlson Rezidor, South Asia. He further states "this trend is not unique to India; it happens all over the world and more so, when economy is not doing very well. Many Asian, European and American cities have gone through this phenomenon. Primarily it is slowdown of economy that has brought this upon us. Funding and high interest rates force investors to be cautious and look for equity funding/ collaboration or exit". "The sliding of rupee has also attracted interest from international investors. I understand that over 60 branded hotels are in the market. Some foreign investors and equity are looking at them" says Khachru

\section{VISA Issues}

According to Vivek Nair, 2014, India was able to attract a mere 6.85 million foreign tourists in 2013, ranking $41^{\text {st }}$ in the world. It is indeed disappointing to compare this performance with some of our competing destinations: Singapore -15.5 million, Malaysia -25.7 million, Thailand -26.7 million and Turkey -35.6 million. Over the years, various systematic impediments have hamstrung our sector's ability to translate the country's ample potential into a correspondingly high market share in the world tourism. A major constraint has been our onerous visa application process which is often fraught with the long delays, excessive documentation and archaic bureaucratic procedures, thereby deterring potential tourists. It has thus become vital for India to urgently address the entrenched inefficiencies in its existing visa structure in order to position itself favourably against competitors. Going forward, it will also be important for us to ensure a seamless and differentiated visa mechanism to reflect the individual requirements of specific market segments such as medical tourists, MICE visitors etc. In February 2014, the Government of India has announced historic measures to significantly liberalise our country's visa norms. As per the new policy, India is poised to offer Tourist Visa-on-Arrival and Electronic Travel Authorization to the citizens of 180 countries. The Government has indicated that it will take five six months for the respective departments to put in place the requisite infrastructure in terms of technology and trained personnel. It is believed that revised visa norms will be a game changer for India's Tourism and Hospitality Industry in the days ahead and our FTAs will be double to 12 million within the next five years. So hotels have to gear up to adapt to various technologies which change quite frequently.

\section{Technology related Issues}

Luxury hotel chains now understand the need to integrate smart technology with their services. Louis Sailer, general manager, The Leela palace New Delhi says "we have taken the guest experience to a level above with the personal welcome message by general manager on the in-room internet protocol based touch phone, use of smart technology like iPads, iRemotes and handsfree bathroom phones as reported by Sudipta Dev, 2014. Though, the challenges of keeping up with the fast pace of technology is difficult and expensive alas guests have increased the use of Internet for online reservations in hotels. As the number of reservations made via the Internet continues to increase, and this percentage is increasing every year, hotels cannot afford not being connected. If the potential guest cannot book online, a reservation will be made at the competitor's web site according to Wang Jin-zhao, Wang Jing 2009. Future will see greater adoption of cloud services while trends 
like Big Data analysis - to understand guest behaviour and demands will become more and more important. Social media will continue to be a dominant influence in the industry. The rapid pace of technology innovations has changed the expectations of the guests which is a challenge that most companies constantly face. Free fast Wi-Fi is a hygiene factor for most guests. They also expect to be able to book online and do other hotel related tasks on whatever devices they happen to own. So, hotels must therefore provide the expected amenities and keep pace with innovation in order to ensure web-based features work on wide range of devices. Days of hoteliers trying to make the hotel room mimic the home are over; it is just not feasible to keep up. What you put into the room today will become outdated vary quickly as the technology cycle is so much faster than the hotel refurbishment cycle says Gopal Rao, director sales and marketing, South West Asia, IHG. He says that minimalist strategy works with three key technology basics in room in place: Great high definition TV, high quality bandwidth, and media panel that can allow the guest to connect their devices to the TV through USB, many power charging sockets etc. As a business hotel, one of the features in all the rooms in Holiday Inn Mumbai International Airport is iPod-docking station. Besides serving as a charger, it has in-built speakers to connect to the iPods, and also has an alarm clock. The LCD screens in each room are retractable and have a media hub. All the rooms are sound proof and have electronically controlled window shades for the bathrooms. In the room guest is provided with Connectivity Panels to connect their Laptops, iPods, video cameras and gaming consoles to the in-room TV.

\section{Human Resource Management}

The first lesson that one learns in the hospitality industry is putting the customer first. However, what one forgets is that probably the most effective way of getting highly satisfied customer is by putting employees first. This is because satisfied employees lead to satisfied customers. Perhaps nowhere this truth is more relevant than in the hospitality industry. Unfortunately the Indian hospitality industry suffers from high rate of attrition. The retention rate of employees in Indian hospitality industry is extremely low, mainly due to the employees' dissatisfaction with low pay and long working hours. The manpower situation in Indian Hospitality industry is quite serious. According to Lalit.K.Panwar, the former Vice chairman and Managing Director of ITDC Ltd. The industry requires 150,000 persons per year whereas supply is only 50,000 per year. This leads to the shortage of 100,000 persons per annum. A Cushman \& Wakefield report states that "One of the main causes of concern for Indian hospitality industry is the lack of adequate manpower given that hospitality is one of the most labour intensive service sectors and depends completely on the experiential and repeat value of the business. The current supply of skilled/professionally trained manpower is estimated to be a very dismal 8.92 percent to the total requirement as per a study commissioned by the Ministry of Tourism. The study anticipates a rapidly widening gap towards 2016 (to 2017), taking into account the attrition rate and retirement and supply from both government and private programs." The high rate of attrition in the Indian hospitality industry is definitely not beneficial to the employer as it results in increasing costs in way of hiring costs, training costs and loss of productivity, loss of company knowledge which the employee takes away with her/him (like knowledge of the company and its customers, etc.), interruption of customer service and goodwill of the company. According to sources, attrition in the industry currently hovers at 25-30 percent - across different levels. To check this, hotel companies have announced considerable salary hikes over the last few years which have resulted in employee cost going up.

One of the effective strategies to check attrition, which most hoteliers cite is train, retrain and retain. In-house training facilitates the employees to keep abreast of the recent developments and trends which will not only benefit the hotel but also the employees. For retention of employees, focused training and development initiatives should be amalgamated with employee counselling and guidance. "It is also necessary to encourage overall development of the employees, by providing them with the opportunity to increase their knowledge through professional programs and courses," averred E. Balaji, CEO, Ma Foi Management Consultants. Regular training programmes for the employees are needed which can give them greater scope for career development. Overall, greater efforts need to be made by the Indian hospitality industry to track the employee turnover and fathom the reasons on why it is so high. It is not only important for the hotels' management to better understand their role in retaining employees, but they must also pass on this knowledge to their line supervisors so that they too can better understand on how to motivate and treat their respective team members with due respect and recognition.

\section{Safety and Security}

Shweta Ramsay in 2014 has reported that, since the 26/11 attack the hospitality industry has continuously been fighting with every challenge in respect with terrorism and other security risks by adapting to new technologies and training the security personnel and other employees as well. Today, there is a sea change in terms of security to protect guests and property from any kind of damage. Before 2011, hotel staff did not focus a lot on the security department. It was just a supportive department that focused on guest related 
operations. However, after 2011, there was a drastic change in thought process of hotel managements. People started security centric programmes and protocols. Good amount of money was pumped in to enhance the security of guests and the property. Extensive awareness and training schedule was created for the guards and security personnel. Newer hotels under development relooked at their design aspects with greater attention given towards integrated surveillance systems, advanced lock and access control systems, and sophisticated asset protection tools. Today, business travellers and corporations, especially, are more concerned with the safety of their traveling employees. Today, safety and security is becoming a sales differentiator for many hotels. In recent years, wireless internet access has become a standard for the hospitality industry. In fact, 70 percent of the guests surveyed have stated that they do not prefer to stay in the hotel where Wi-Fi access is not provided. However, offering free or paid internet is at the discretion of the hotel, but offering secured and managed internet is the need of the hour. According to the Trustwave 2012 Global Security Report, hospitality industry has four times consecutively ranked on top of the list for data breaches. It shows that most of the hospitality companies in the world are unaware about managing the access network as stated by Samiksh Aggarwal, Asst. Vice President sales- Data networks, Elitecore technologies Pvt. Ltd.

\section{Refrences}

[1]. Varuni Khosla \& Divya Sathyanarayanan, ET Bureau, April 102014 in article named "Hoteliers hope next govt to drive turnaround in sector" http://articles.economictimes.indiatimes.com/2014-04-10/news/49031679_1_fhrai-next-government-restaurantassociations

[2]. Manav Thadani, Juie S. Mobar September 2013 in HVS India report "CRITICAL CHALLENGES FACED BY HOTEL OWNERS IN INDIA"

[3]. Aditi Shah in FEB, 2014 IN ARTICLE "Luxury hotels swap keys in India's economicslump",http://www.livemint.com/Consumer/TsOUCllmwcI05zlW8O17jP/Luxury-hotels-swap-keys-in-Indias-economicslump.html viewed on 14-04-2014 at $12.25 \mathrm{pm}$.

[4]. Varanika Vij, August 2013, Destination report - Western India Hospitality: the four big concerns, a cross section publication HotelScapes - All about Hotels and Hospitality", volume 2. Issue 7, August 2013.

[5]. Navin Berry August 2013, Article "The Big Hotel Sale" under The Big Story Column, published in a cross section publication HotelScapes - All about Hotels and Hospitality, volume 2. Issue 7, August 2013

[6]. Vivek Nair, March 2014, The new tourist visa regime: A game-changer for our industry, Hony. Secretary, Federation of Hotels and Restaurant Association of India in FHRAI Magazine March 2014, Volume 14 issue 3.

[7]. Sudipta Dev April 2014 in an article named "Tech Next" in Food and Hospitality World, india's foremost food and hospitality publication, Volume 2 No.14, www.foodandhospitalityworld.com

[8]. Ashok Malkani, October 2013, in Cover story Attrition Challenges in Hotel Business Review- n exclusive business magazine for the hotel industry, September-october 2013, Volume - 9 number-5

[9]. Shweta Ramsay, June 2014, in cover story Is hotel Safety \& Security priority today ? in Hospitality Biz India .com for the hospitality professionals. http://www.hospitalitybizindia.com/printArticle.aspx? sid=5\&aid=19448 